\title{
THE DEVELOPMENT DESIGN OF CURRICULUM 2013 FOR FIQIH LEARNING THROUGH A HUMANISTIC APPROACH
}

\author{
Anika Monaziroh ${ }^{1}$, Choirudin ${ }^{2}$ \\ ${ }^{1}$ Islamic Educational Management Department, Universitas Islam Negeri Sunan Kalijaga \\ Yogyakarta, Indonesia. \\ 2Islamic Educational Management Department, Institut Agama Islam Ma'arif Nahdlatul Ulama, \\ Metro Lampung, Lampung, Indonesia \\ Email : anika.muna03@gmail.com¹, choirudiniaimnumetro@gmail.com²
}

\begin{tabular}{l|l|l} 
Received: January 2021 & Accepted: March 2021 & Published: March 2021
\end{tabular}

\begin{abstract}
:
This study aims to describe the design of the 2013 curriculum development and the humanistic approach through the 2013 curriculum (Core Competencies and Basic Competencies) in Islamic jurisprudence subjects at Madrasah Ibtidaiyah (MI). The authors consider that it can later be the best solution for learning Fiqh through a humanistic approach. This research method uses content analysis. Content analysis is a research that is an in-depth discussion of the content of information contained in a mass media (analysis of the content of the object is mainly mass media). The result shows that several curriculum designs in 2013, including scientific discipline curriculum design, community-oriented curriculum design, student-oriented curriculum design, technological curriculum design, and Fiqh curriculum material. A balance must be reached between the materials that describe the principles of humanistic education. In this study, the authors also provide a solution that the concept of Fiqh learning uses a humanistic approach.
\end{abstract}

Keywords: 2013 Curriculum, Design, Figh, Humanistic

\begin{abstract}
Abstrak:
Penelitian ini bertujuan untuk mendeskripsikan desain pengembangan kurikulum 2013 dan pendekatan humanistik melalui kurikulum 2013 (Kompetensi Inti dan Kompetensi Dasar) pada mata pelajaran Fiqih di Madrasah Ibtidaiyah (MI). Hal ini nantinya mampu menjadi solusi terbaik untuk belajar Fiqh melalui pendekatan humanistik. Metode penelitian ini menggunakan analisis isi dengan pembahasan mendalam tentang informasi yang terkandung dalam suatu media massa (analisis isi obyek terutama media massa). Hasil penelitian menunjukkan beberapa desain kurikulum tahun 2013, antara lain desain kurikulum disiplin ilmu, desain kurikulum berorientasi komunitas, desain kurikulum berorientasi siswa, desain kurikulum teknologi, dan materi kurikulum Fiqih. Keseimbangan harus dicapai antara materi yang menggambarkan prinsip-prinsip pendidikan humanistik. Dalam penelitian ini, penulis juga memberikan solusi bahwa konsep pembelajaran Fiqih menggunakan pendekatan humanistik.
\end{abstract}

Kata Kunci: Kurikulum 2013, Desain, Fiqh, Humanistic 


\section{INTRODUCTION}

Curriculum design refers to the way we position curriculum components. Designing a curriculum means developing a curriculum prepared by the mission and vision of the school. The curriculum is a set of plans and arrangements, content and materials, and methods used as guidelines for teaching activities (Gunawan, 2017). Designing a program is not an easy job. Curriculum development in 2013 is part of a strategy to improve educational achievement. According to the plan on an objective, progressive and systematic process make positive improvements in the education system and curriculum development. Every time there is a change or growth that occurs worldwide, the school curriculum is affected. School curriculum development is carried out after the curriculum development stage or after forming a new curriculum.

Humanistic education is a series of humanities originating from humanistic thinking. It is related to understanding society (humanistic) as a basic concept of human knowledge. Since its inception, the Islamic education system has been on social values, in which the essence of Islam is to be a human religion. Islam takes the human aspect as the direction of education. School education and the learning process are not very democratic. Students lack a place to develop imagination and creativity based on their own opinions. Creativity and critical thinking are valuable assets for children to overcome challenges and increase competitiveness (Anwar et al., 2019; Sumantri \& Ahmad, 2019; Wahyudi et al., 2021).

Curriculum development in Indonesia cannot be separated from the objectives of national education. The National Education system explains that the curriculum is a set of plans, arrangements regarding content, learning materials, and methods used as guidelines for regulating learning activities to achieve specific educational goals (Miswanto, 2015). Madrasah as a formal educational institution, systematically plans various environments, where Figh is one of the fields of science with Islamic Sharia that specifically discusses legal issues that govern various aspects of human life, both personal life, society, and human relationship with its creator. In undergoing religious activities, people use Figh as a guideline. Therefore, in the world of formal education, the development of potential learners, both cognitive, affective and psychomotor aspects become the task of educators that are also required to make students able to get the learning experience.

Fiqh subjects in Madrasah Ibtidaiyah (MI) usually contain worship rules that can raise students' religious awareness. After studying the material in Figh subjects, students should be motivated and practice it daily. But in fact, there are still many students who can do worship, for example, prayer, zakat, fasting, but it is always challenging to practice it in everyday life.

The problem of learning Figh in practice is more toward the cognitive aspects. In that case, it is necessary to design a more comprehensive curriculum (humanist) in the future. Based on humanist values, from the beginning, the Islamic education system is basically a religion of humanity. Islam makes the humanities the direction of education. It is doubtful that the concept of Islamic humanistic education is applied in Western education (Rahman, 2017). 
The real purpose of education is to help people attain full human survival. Education aims to improve people's lives. The most distinguishing element between humans and animals is the gift of the reason given by God. In this way, only people can experience the educational process. According to existentialists, humans are born in the world in a helpless state and forced to take responsibility for their survival (Idris \& Za, 2017). Humanizing is an educational process based on increasing intellectual abilities and must explore and improve all the potential embedded in humans, whether it's academic abilities, emotional abilities, and spiritual abilities. This study aims to determine curriculum development and humanistic approaches through the 2013 curriculum (core and basic competencies) in Islamic Elementary School (MI).

\section{RESEARCH METHODS}

This research uses content analysis. Content analysis is concerned with in-depth discussion of the content of information contained in a mass media (analysis of the content of the object that is mainly in mass media). All objects studied are mapped in the form of writings or symbols and then given interpretations one by one. Content analysis is a research technique that seeks to create inferences that can be imitated and valid data by paying attention to the context. The main objectives in content analysis are to describe sample documents, limit the content of categories, i.e. content that depends on the purpose of the study, limit record and context units, and limit enumeration systems. The three strategic steps of content analysis are to establish a research model, search for primary data, and seek contextual knowledge so that the research conducted is not in a vacuum (Arafat, 2019).

\section{FINDINGS AND DISCUSSION}

The curriculum is derived from Latin, which means the road or path traversed by the train and adopted in education. Therefore, it concerns the collection of eyes, the student curriculum that the teacher must teach or study, or the set of topics set by the school for the case to review. Students graduate and receive a diploma. This understanding is an opinion for the older curriculum, where the focus is on curriculum content. In some cases, this definition is still used today (Gunawan, 2017; Sparapani et al., 2014).

A curriculum is a tool used to achieve the goals of national education, taking into account the stages of development of students and the ability to adapt to the environment (Wahyudi et al., 2019), the needs of national development, the development of science and technology and the development of arts, as well as the types and levels of each educational module. Based on these regulations, it is necessary to add that national education needs to consider national culture and Pancasila and the 1945 Constitution (Gumbira \& Wiwoho, 2019). According to Deis et al., (2020) curriculum development is a complex process because it involves discussing curriculum formulation in schools and accompanied by intensive evaluation and improvement of curriculum elements (including target components). Different perspectives that govern curriculum development create diversity in curriculum organizations (Misbah et al., 2020). On the other hand, the development of PAI curriculum is 
also derived from inputs from various stakeholders, education experts and curriculum experts.

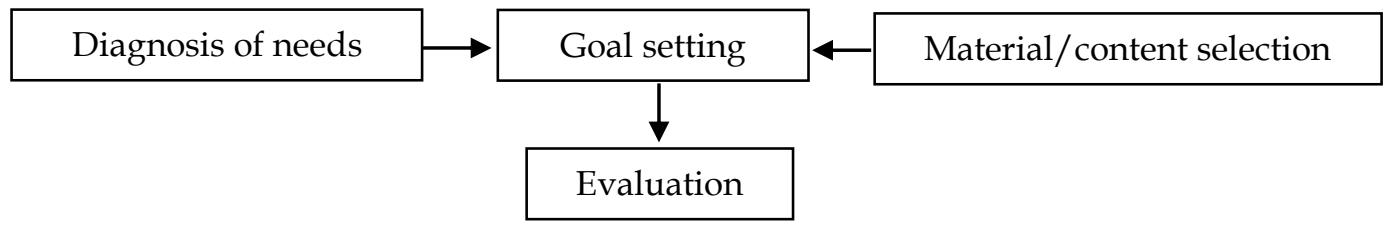

Figure 1 : PAI Curriculum Development Ideas Scheme

Figure 1 shows that the principles implemented in the process of PAI curriculum development conducted by teachers of Islamic Regions Education are the principle of relevance, flexibility, continuity or sustainability, practical principles that are easy to implement, and the principle of effectiveness. From this explanation, it can be concluded that curriculum development planning is a process of organizing a curriculum that includes objectives, content, learning experiences, and evaluation. These activities are used as guidelines in educational activities. In designing the curriculum, the curriculum elements developed include the relationships between one and another, the organizational principles, and the things needed to implement them. When designing the curriculum, the following steps need to be taken into account: Determining the mission of the institution and the needs of its educated users, evaluating student needs, determining curriculum objectives, selecting educational strategies, defining curriculum objectives, selecting an educational system, implementing new courses, assessing and providing feedback for improving the curriculum (Pak et al., 2020).

One of Tyler's colleagues, Hilda Taba, describes Tyler's curriculum development model: theory and practice. She proposes a seven-step model for curriculum development. These steps are: diagnosing needs, formulating specific goals, selecting content, organizing content, selecting learning experiences, organizing learning experiences, evaluating. Fred Percival and Henry Ellington think that curriculum design is a process of curriculum design development, verification, implementation, and evaluation. Curriculum design can be interpreted as a design or layout of elements that only includes objectives, content, learning experiences, and assessments (Rapanta et al., 2020).

Existing curriculum designs include the following: first, curriculum design in disciplines; this curriculum development design is oriented towards students' intellectual development by subject experts in their respective fields. The forms of this curriculum organization are as follows: subject-centered curriculum, correlated curriculum, and integrated curriculum (Drake \& Reid, 2018).

Second, community curriculum design; the assumption based on this form of curriculum design is that schools' purpose is to serve social needs. Therefore, the community must use the basis for determining curriculum content. There are three perspectives on curriculum design oriented toward people's lives, namely: the status quo perspective, which means that curriculum design is directed at preserving the cultural values of the community; based on 
this renewed view, curriculum development aims to improve the quality of society itself further. Besides, future perspectives are often associated with social reconstruction plans that emphasize developing links between the curriculum and community, politics, and the city's economic life (Wahyuni, 2016).

Third, student-oriented curriculum design; the underlying assumption of this design is to organize education to help students. Besides, Palupi (2018) gave the main object of knowledge, especially in the learning process, the students' role is significant. Students can determine the success of learning through intelligence, athletic ability, experience, will, and commitment to the teaching and learning process, which will not force them (Choirudin et al., 2021). Therefore the curriculum must be able to adjust to the rate of student development. When designing a student-oriented curriculum, it is necessary to pay attention to the following points: The curriculum must adapt to its growth. The curriculum content must include skills, knowledge, and attitudes that are considered useful for the present and future. Children should be treated as lessons they are trying to learn, meaning that students should be encouraged to participate in various learning activities, not just getting information from the teacher. They are studying actively according to the students' interests, talents, and development level, meaning that what he has to learn is not decided and processed from the teacher's perspective or other perspectives, but from the student's perspective.

Fourth, the engineering curriculum design, the engineering curriculum has the same content as the classical education stream; the latter emphasizes the curriculum's content, not for the preservation of science, but the mastery of abilities. Extraordinary abilities are divided into narrow skills or specific skills and finally separated into behaviors observed and measured (Chaerul, 2019). Many experts have developed various lesson plans. Serdyukov (2017) divides the design into five types: cognitive development models, technical curricula, self-realization curricula, social reconstruction curricula, and academic rationality curricula. Broome (2014) divides curriculum design into four models: humanistic curriculum model, social reconstruction curriculum, technical curriculum, and educational curriculum. Saylor, Alexander, and Lewis as quoted by Adirika (2020) divided curriculum design into subjects, specific qualifications or specialized curriculum, curriculum as a process, curriculum as a social function, and unique curriculum. Longstreet and Shane divide curriculum design into four designs: community-based curriculum, child-centered curriculum design, knowledge-oriented curriculum, and selective curriculum design (Maas, 2019).

According to the Minister of Religion Regulation No. 912, the 2013 Curriculum is the latest curriculum applied in Indonesia. The 2013 curriculum is a development from the previous curriculum to respond to various internal and external challenges. Furthermore, according to Rusman, the point of emphasis for curriculum development in 2013 is to improve mindset, strengthen governance, curriculum, deepen and expand the material to enhance 
learning and adjust the learning load to ensure the desired fit with what is produced (Rusman, 2015).

Curriculum development activities are pursued with a systematic pattern of arrangements and certain steps so that an effective curriculum can be produced. The pattern of arranging curriculum components is called the Curriculum Organization or Curriculum Design. Meanwhile, the systematic steps in curriculum development are called the Curriculum Development Model (Palupi, 2018). The stages of the process of developing the HumanisticBased Islamic Religious Education curriculum implemented in MI, are as explained in the following chart:

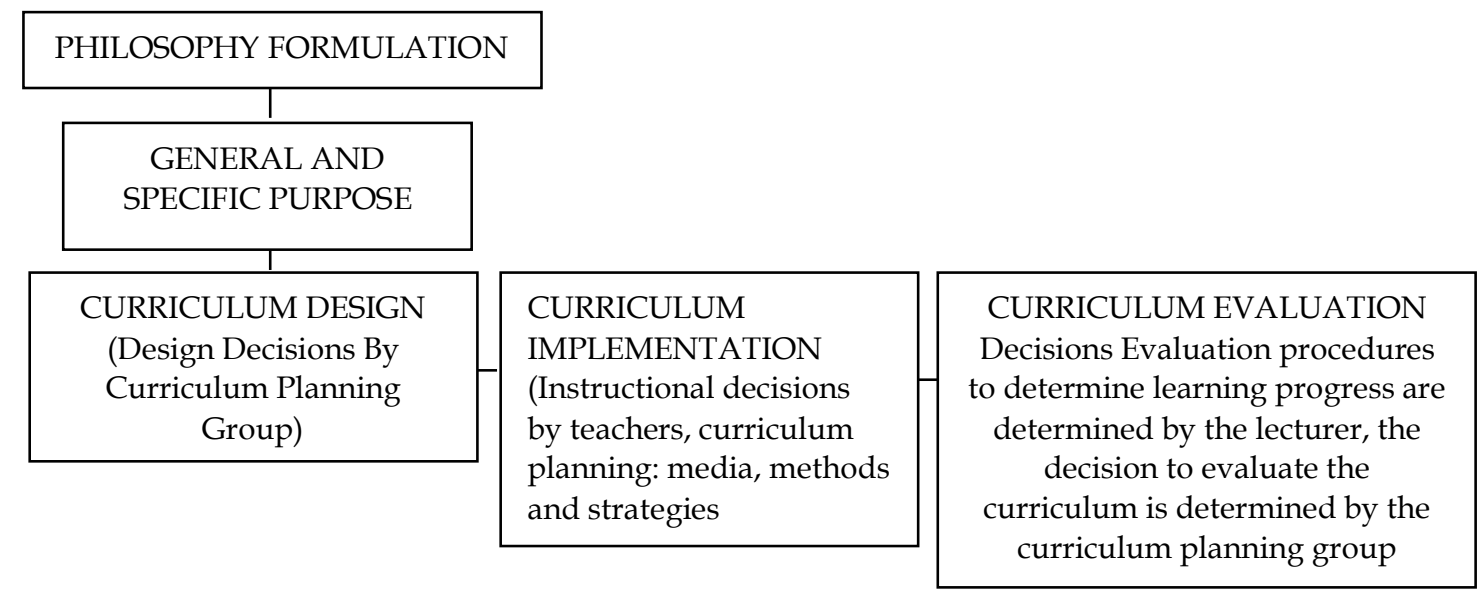

Figure 2 : Saylor, Alexander and Lewis Model Curriculum Development Step Scheme

Figure 2 shows that centralized curricula tend to be more structured and orderly, and it is easier to ensure a uniform and standardized approach to teaching and learning. A centralized curriculum allows better access to a broad set of skills but is less sensitive to local needs. Such decentralized curricula tend to better suit students' local needs and often ensure better tenure by teachers. Decentralization allows various approaches to design and delivery and compares strengths and weaknesses, especially in the humanistic approach.

The humanistic approach was developed by humanistic education experts. This curriculum is based on personal education, namely John Dewey (incremental education) and JJ Rousseau (romantic education). This process gives students a critical position. They assume that the child or student is the most important in education. It is a central topic of educational activity. They believe that students have the ability and strength to develop. Humanities educators also follow the Gestalt concept, namely that the individual or child is one whole unit. Education is not only for physically and mentally complete people but also for the development of society and emotions (emotions, attitudes, feelings, values, etc.) (Nasution \& Suyadi, 2020).

In general, education aims to help humans achieve complete human survival. Education also aims to increase the level of people's intake. The element that humans can better distinguish humans from animals is the verbal ability given by God. In this way, only humans can experience the educational 
process. According to existentialists, humans are born in the world in a helpless state and forced to take responsibility for their survival. The human concept is a process of interaction between humans and the environment as well as changing challenges (Halimi, 2018).

Humanistic education emphasizes humanizing human-oriented learning models that can reflect the fulfillment of human needs for students. The central concept of humanistic knowledge, according to Mangun Wijaya, is "respect for human dignity, to create a learning environment that makes students free from great competence, high discipline, and fear of failure (Winarno et al., 2019). The humanistic approach in the Figh curriculum is student-centered and prioritizes students' emotional development as an integral part of the learning process. Humanistic educators believe that students' psychological and emotional wellbeing must be central to the curriculum so that learning can achieve maximum results.

The results showed that students' self-concept was positively correlated with academic achievement. Students with low self-esteem have more significant learning difficulties than students with positive self-concepts. The humanistic approach is that if students' self-esteem is fully developed, they will be more effective in learning and working. Students involved in the design and implementation of the course will be responsible for their success. There is no excessive tension in a learning atmosphere full of mutual trust, cooperation, and joint care; learning outcomes will increase.

The teacher's role in the humanistic approach has been described as one where educators adopt warmth and a caring presence (Darling-Hammond et al., 2020). It facilitates experiences where students are encouraged to explore their interests and ideas (Rapanta et al., 2020) and present imaginatively to situations. Learning is challenging, with more than one answer. Caring relationships take time to develop. It is recommended that students and teachers stay together for several years to foster a deeper understanding and care for one another (Broome, 2014).

Humane learning is defined as learning that leads to a humane process. Human education is the process of guiding and developing primary human resources, including material and spiritual, based on equal respect for other social values. Humanism is part of the learning method. The humanitarian approach to education emphasizes positive development. A technique that focuses on human resources to find and find the skills they have and develop these skills (Muhtar \& Dallyono, 2020).

The next step is to design the teaching materials referred to as the syllabus through the humanistic learning method in Fiqh lessons. The material introduced in the textbook is based on $\mathrm{KI}$ and $\mathrm{KD}$ and indicators that students must achieve in these subjects. The material is as attractive as possible and contains humanity approach in the 2013 curriculum. The author believes that the Figh learning method through the humanistic process provides solutions to all problems in practice. According to the author, this may not be the best method, and the spirit of human principles has not been explained. In learning, 
it should describe a humanistic "spirit" in each part of education, covering the following aspects: learning objectives, learning strategies, learning methods.

So that the goal of learning Figh through the MI level humanitarian method is to be applied appropriately, several principles must be followed in learning. There are three primary learning principles: (1) in classical conditions, and the theory was developed based on the results of experiments conducted by Russian national scientist Iva Pavlov (1849-1936). Classical preparation is a learning process in subjects through habits (practice) that focuses on the process of providing stimuli (stimulus) to obtain a specific response (stimulus-response relationship) without using reinforcement. According to adaptation theory, learning is a process of change that occurs due to conditions that trigger a reaction. (2) Instrumental (Operant) Conditioning research on conditioning operants, starting from a series of Thorndike experiments. He claimed that in the conditioning operant, the law of selecting the outcome of multiple random responses was only positive. This process is similar to evolution. The essential survival rules are chosen from a random set of variants of a species, and the only change will increase the survival rate of a species. Hence, the law of effect increases the survival of the species. For example, a mouse in running a cage roams, kissing objects around it, and scratching walls. (3) cognitive learning, the term refers to the processing of environmental information received through the five senses. Simultaneously, knowledge can lead to relatively permanent changes in behavior due to education or experience. Cognitive learning is the result of experience or practice (Zainiati, 2017).

According to the author, the proper way of learning is used in Islamic Figh learning. Through a humanistic approach is a contextual learning strategy, and the learning strategy is Quantum Teaching. According to Ramadhani \& Ayriza (2019) Quantum Teaching (QT) is a teaching system that applies new ways to facilitate the learning process by combining artistic elements and targeted achievements. Learning model with the principle or design of "tandur". The teacher must master the model or system to create an exciting and relaxing learning process in the classroom and hope to achieve more learning goals than previously planned. Learning with this approach respects the domain that exists in students, as well as the cognitive area. So that in the learning process, the human values that live in students get attention to be developed. In addition, the humanistic learning philosophy also requires learning not only to stop in cognitive aspects but also to involve practical aspects (psychomotor and emotional).

Rismaningtyas et al,. (2020) believes that the characteristics of contextual learning include confidence in spatial memory, integration of various disciplines, the value of information based on student needs, and the relationship between information and students. Prior knowledge and actual evaluation of students through the practical application or practical problemsolving. More specifically, according to Johnson in (Darling-Hammond et al., 2020) identifies eight components, namely, building meaningful relationships, important work, learning self-regulation, cooperation, critical and creative thinking, caring for individuals, achieving high standards, and using 
authenticity. By referring to the characteristics of contextual learning, the application of contextual knowledge in Figh subjects through a humanitarian approach can be achieved in the following ways: guiding students to remember understanding of the material being taught, guiding students to experience the worship immediately led such as wudhu', congregational prayer, dhikr, and providing information about student activities is essential. Suitable for their life. Quantum learning places great emphasis on a fast learning process with high success. The quantum learning model is almost the same as a symphony. When we watch a symphony, many elements factor into our musical experience. We can divide these elements into two categories: context and content (Rezeki \& Asrizal, 2019).

According to the author, quantum learning can be applied in humanistic jurisprudence through the following arguments: 1) by humanistic nature. The position of humans as learners (students) is the center of attention. Selfpotential, mental abilities, motivation, and so on from students can develop optimally. 2) to be constructive; thus, quantum learning emphasizes the importance of integration between potential self-factors because students and the environment will get optimal understanding. 3) quantum learning takes values and beliefs as an essential part of the learning process. Without specific values and beliefs, the learning process is meaningless. Quantum learning integrates the whole body and mind into the learning process. Quantum Teaching emphasizes meaningful terms and value systems and humanistic education. Of course, when students become adults, this can certainly make a difference.

The learning method of humanities Figh is a learning method in the media of transformation to achieve the expected competencies in learning. Learning tools that support humanistic Figh learning include visual, audiovisual, and natural methods (Rosyad, 2020). The teacher must use this tool to achieve learning goals quickly and motivate them to do what the teacher recommends. Learning resources for subject matter as follows: MI book material. As the primary reference. Then there are other supporters such as magazines, announcements, internet books, and presenting original actors such as doctors and psychologists. Human Figh learning assessment can be completed through pre-test, embedded test, and post-test (Irhamni \& Saifuddin, 2018). Adequate humanitarian material is evaluated in the classroom and outside the school, such as in the school, community, and home environment. It is necessary to find a complete picture of students' understanding and application of material knowledge in everyday life. The assessment results can not only be communicated to the student guardians in the form of numbers. Still, they can also be descriptions or descriptions of the students' abilities for each ability model. In an evaluation based on a humanistic approach, teachers need jurisprudence to be evaluated/tested on cognitive and three domains (mental, emotional, and psychomotor).

When designing a curriculum, there are the following steps that need to be taken: determining the mission of the institution and the needs of training users, evaluating the conditions of training participants, setting curriculum 
objectives, selecting educational strategies, implementing the new curriculum, assessing and providing feedback for curriculum improvement. Therefore, with various positive influences from outside and inside, curriculum development aims to target the expected educational goals and hopes that students can face their future well. Therefore, curriculum development must be preventive, adaptive, and implementable.

Furthermore, the authors limit the problems in discussing the curriculum in MI Figh subjects. Regarding Core Competencies and Basic Competencies in MI Figh subjects. Based on the minister of religion of the Republic of Indonesia Number 183 of 2019. One of the reasons for the change in the KTSP curriculum towards 2013 is: anticipating future competency needs, referring to best practices, studying a synthetic approach. Moreover, if it leads to the 2013 curriculum (K13), the Figh curriculum in question is, of course, in every academic unit/institution. Therefore, the Core Competencies and Basic Competencies of MI Figh are still standard references for almost all MI in various regions, even throughout Indonesia. It is necessary to pay attention to the content of Core Competencies and Basic Competencies in this subject. As stated in the previous explanation, the author concludes that all the substances contained therein can be divided into two groups: the habl of Allah and habl min al-Nas. In this way, the MI Figh material can be divided into two, namely:

First, Habl Min Allah: Class 1 discusses purification. Class II includes adhan and iqamah, congregational prayer, dzkir, and prayer. Class III includes: provisions for rawatib sunnah prayers and practicing rawatib sunnah prayers, congregational prayers, qashar and emergency, fasting in Ramadan and prayers for breaking the fast, last prayer, witir prayer. Class IV includes zakat fitrah, Idain prayers, Friday prayers. Class $\mathrm{V}$ includes sacrifice (provisions regarding animal slaughter, sacrifice, practicing the sacrificial method), hajj, and umrah. Class VI includes: eating halal food, keeping haram food away, drinking halal drinks, and keeping haram drinks away.

Second, Habl Min Nas: grade IV, discusses zakat fitrah, donations, and alms. Class V includes sacrifice, hajj, umrah. Class VI includes buying and selling, borrowing. The Figh subjects in the Core Competencies and Basic Competencies are ideal compositions that fit the relationship between habl min Allah and Nas's habits. It can be concluded that the existing curriculum has fulfilled humanistic principles, namely the balance of situations and teaching materials. "Who is human, and what is the purpose and function of the creation of man by God."

According to the author, there is still minimal discussion about Figh, limited to studying interpersonal relationships in a narrow sense. This material can be expanded by adding material that describes the relationship between humans and the environment and the natural environment. Therefore, with this material, it is possible to increase students' visual awareness and make them interested in the background and nature because the ecosystem must be preserved, cared for, protected and preserved. The development of the MI Figh curriculum (Core Competencies and Basic Competencies) will be improved in the future. When teaching the relationship between humans and others, the 
environment and nature, the form must be made more concrete. In other languages, material related to social interaction (ecology) also has a place in MI Figh material. To better reflect the human content, namely the balance of relevance between the habl min of Allah, the habl min an-Nas, and the natural habits (social interaction), this is contained in the Figh of worship. This is explained in terms of "religious beliefs" and ecological issues.

In addition to providing more complete and humane material and providing students with answers to real-life questions about the life around them, it is also essential to introduce ecological problems to students from an early age. Especially when we call humanity's duties and functions as the Khalifah of Allah fil-Ard, society must prosper the earth, protect natural ecosystems, and protect the environment.

The definition of ecological Figh is divided into two, namely Figh and ecology. Figh is the practical knowledge of syara's laws, taken from tafshili (detailed) arguments. At the same time, ecology is defined as the unity of space and all objects, forces, conditions, and living things (including humans) and their behavior that affects humans' nature, survival and well-being, and life. Therefore, ecological Figh is a discovery about sustainability and environmental law and the concept of environmental law. It exists because the Koran and the following versions only explain the principles of ecological protection and restoration.

In the field of Figh, he still focuses on theism-centric themes observed in a group of people who know Figh, who understand that Figh is only limited to worshiping Allah, such as prayer, fasting, zakat, and going on hajj. As a result, Figh related to ecology is still being neglected. In the context of the current environmental crisis, ecological Figh has become very urgent. People need to believe that pollution of rivers and oceans, reckless deforestation, and killing of protected animals are grave crimes through ecological Figh.

From the explanation of the ecological principles above, it is undoubtedly beneficial for MI students. You can choose urgent and practical problems according to your needs. Before being abolished, this social environment material had become the subject of Islamic Figh. The author believes that the importance of this theme material is to educate students' social attitudes to shape social transformation in broader society, so this ecological material needs to be reintegrated into the MI theme curriculum. by Core competencies and Basic Competencies.

\section{CONCLUSION}

Curriculum design is a knowledge-based design based on the design of the subject structure. Therefore, the design model is also called a curriculum model for academic subjects that focuses on students' intellectual development. The curriculum design is divided into 4: the first, the curriculum design of scientific disciplines; the second, the community-oriented curriculum design; the third, the curriculum design that is student-oriented, and the last is the design of the technological curriculum. The 2013 curriculum is a curriculum that is developed and refined from the previous curriculum. The curriculum for 
MI Figh subjects. Has described the humanistic principle because it includes the relationship between the habl min of Allah and the habl min al-Nas. Therefore, no material regulates human relations with the environment and nature (social interaction). According to the author, the addition of humanistic and holistic Figh material between habl min Allah (worship Figh) with habl min al-Nas (mu'amalah Figh), and habl min al-Alam (ecological Figh). To achieve humanistic, learning goals must be manifested in education, which includes the following aspects: learning objectives, learning strategies, learning methods, and learning assessments.

\section{REFERENCES}

Adirika, B. N., \& Okolie, V. C. (2016). Examining Models of Curriculum Development and Processes: Implications for African Educational Heritage And Review. Social Science and Humanities Journal, 1(5), 295-313.

Anwar, M. S., Choirudin, C., Ningsih, E. F., Dewi, T., \& Maseleno, A. (2019). Developing an Interactive Mathematics Multimedia Learning Based on Inspiring Presenter in Increasing Students' Interest in Learning Mathematics. Al-Jabar: Jurnal Pendidikan Matematika, 10(1), 135-150.

Arafat, G. Y. (2019). Membongkar Isi Pesan dan Media dengan Content Analysis. Alhadharah: Jurnal Ilmu Dakwah, 17(33), 32-48. https://doi.org/10.18592/alhadharah.v17i33.2370

Broome, J. (2014). Commentary - The Case for Humanistic Curriculum: A Discussion of Curriculum Theory Applied to Art Education. The Journal of Art for Life, 5, 1-16.

Chaerul, A. (2019). Implementasi Technological Curriculum pada Model Desain Kurikulum Pelatihan Profesi Guru Vokasional. Judika (Jurnal Pendidikan Unsika), 7(2), 1-10.

Choirudin, Anwar, M. S., Azizah, I. N., Wawan, \& Wahyudi, A. (2021). Pengembangan LKPD Matematika Berbasis Kaligrafi dengan Pendekatan Guided Discovery Learning. Jurnal Pendidikan Matematika (JPM), 7(1), 5261. https:/ / doi.org/10.33474/jpm.v7i1.6738

Darling-Hammond, L., Flook, L., Cook-Harvey, C., Barron, B., \& Osher, D. (2020). Implications for Educational Practice of The Science of Learning and Development. Applied Developmental Science, 24(2), 97-140.

Deis, N., Koch, C., Dreimüller, N., Gaitzsch, E., Weißkircher, J., Jünger, J., \& Lieb, K. (2020). Development, Implementation, and Evaluation of a Curriculum for Medical Students on Conflicts of Interest and Communicating risk. GMS Journal for Medical Education, 37(1), 1-20.

Gumbira, S., \& Wiwoho, J. (2019). The Implication of the Globalization on The Pancasila-Based Principles of Local Democracy in Indonesia. Padjadjaran Jurnal Ilmu Hukum (Journal of Law), 06(02), 361-378. https://doi.org/10.22304/pjih.v6n2.a8 
Gunawan, I. (2017). Indonesian Curriculum 2013: Instructional Management, Obstacles Faced by Teachers in Implementation and the Way Forward. Proceedings of the 3rd International Conference on Education and Training (ICET 2017), 56-63.

Halimi, M. F. (2018). Pendekatan Humanisme dalam Perspektif Pendidikan Islam. Rausyan Fikr: Jurnal Pemikiran dan Pencerahan, 14(1), 129-142.

Idris, S., \& Za, T. (2017). Realitas Konsep Pendidikan Humanisme dalam Konteks Pendidikan Islam. Jurnal Edukasi: Jurnal Bimbingan Konseling, 3(1), 96-113. https:/ / doi.org/10.22373/je.v3i1.1420

Irhamni, M., \& Saifuddin, S. (2018). Pelaksanaan Pembelajaran Fiqih di Madrasah Ibtidaiyah An Najah Desa Haur Kuning Kecamatan Beruntung Baru Kabupaten Banjar. Darris: Jurnal Pendidikan Madrasah Ibtidaiyah, 1(1), 12-24.

Maas, P. H. (2019). Curriculum Development, Islamic Religious Education, Islamic Elementary School AL Azhar. Atthulab: Islamic Religion Teaching and Learning Journal, 4(1), 20-28. https:// doi.org/10.15575/ath.v4i1.2850

Misbah, Z., Gulikers, J., Dharma, S., \& Mulder, M. (2020). Evaluating Competence-based Vocational Education in Indonesia. Journal of Vocational Education E Training, 72(4), 488-515.

Miswanto, R. (2015). Pengembangan Kurikulum Pendidikan dalam Perspektif Kurikulum Humanistik (Studi Kasus di Sekolah Dasar Muhammadiyah Karangbendo Bantul). Terampil: Jurnal Pendidikan dan Pembelajaran Dasar, 2(2), 205-224.

Muhtar, T., \& Dallyono, R. (2020). Character Education From The Perspectives Of Elementary School Physical Education Teachers. Jurnal Cakrawala Pendidikan, 39(2), 395-408. https://doi.org/10.21831/cp.v39i2.30647

Nasution, H. A., \& Suyadi, S. (2020). Pembelajaran Pendidikan Agama Islam Humanistik dengan Pendekatan Active Learning di SDN Nugopuro Gowok. Jurnal Pendidikan Agama Islam, 17(1), 31-42.

Pak, K., Polikoff, M. S., Desimone, L. M., \& Saldívar García, E. (2020). The Adaptive Challenges of Curriculum Implementation: Insights for Educational Leaders Driving Standards-Based Reform. AERA Open, 6(2), $1-15$.

Palupi, D. T. (2018). What Type of Curriculum Development Models Do We Follow? An Indonesia's 2013 Curriculum Case. Indonesian Journal of Curriculum and Educational Technology Studies, 6(2), 98-105.

Rahman, M. (2017). Pemikiran Pendidikan Humanistik dalam Islam. Hikmah: Journal of Islamic Studies, 13(2), 111-126.

Ramadhani, M. I., \& Ayriza, Y. (2019). The Effectiveness of Quantum Teaching Learning Model on Improving The Critical Thinking Skills and The Social Science Concept Understanding of The Elementary School Students. Jurnal Prima Edukasia, 7(1), 47-57.

Rapanta, C., Botturi, L., Goodyear, P., Guàrdia, L., \& Koole, M. (2020). Online University Teaching During and After the Covid-19 Crisis: Refocusing Teacher Presence and Learning Activity. Postdigital Science and Education, 2(3), 923-945. https:// doi.org/10.1007/s42438-020-00155-y 
Rezeki, M. S., \& Asrizal, A. (2019). Pengembangan LKS IPA Berorientasi Model Pembelajaran Quantum Materi Pesawat Sederhana, Struktur Tumbuhan dan Sistem Pencernaan untuk Siswa Kelas VIII SMP. Pillar of Physics Education, 12(1), 17-24.

Rismaningtyas, A., Slamet, A., \& Pranoto, Y. K. S. (2020). Implementation of Contextual Based Teaching Materials on Various Work Themes of Primary School Students. Journal of Primary Education, 9(1), 110-119.

Rosyad, A. M. (2020). The Integration of Islamic Education and Multicultural Education In Indonesia. Al-Afkar, Journal for Islamic Studies, 3(1), 164-181.

Rusman. (2015). Model-Model Pembelajaran. Bandung: PT Raja Grafindo Persada.

Serdyukov, P. (2017). Innovation in Education: What Works, What Doesn't, and What to Do About It?. Journal of Research in Innovative Teaching $\mathcal{E}$ Learning, 10(1), 14-33. https:// doi.org/10.1108/JRIT-10-2016-0007

Sparapani, E. F., Callejo Perez, D., Gould, J., Hillman, S., \& Clark, L. (2014). A Global Curriculum? Understanding Teaching and Learning in The United States, Taiwan, India, and Mexico. SAGE Open, 4(2), 1-15.

Sumantri, B., \& Ahmad, N. (2019). Teori Belajar Humanistik dan Implikasinya terhadap Pembelajaran Pendidikan Agama Islam. Fondatia, 3, 1-18. https://doi.org/10.36088/fondatia.v3i2.216

Wahyudi, A., Salamun, S., Hamid, A., \& Choirudin, C. (2021). Strategi Pengelolaan Vocational Life Skill Pada Pendidikan Islam. Jurnal Manajemen Pendidikan Islam Al-Idarah, 6(1), 39-45.

Wahyudi, A., Zulela, Marini, A., Choirudin, B. Ayshwarya, Nguyen, P. T., \& K. Shankar. (2019). Government Policy in Realizing Basic Education Metro. International Journal of Innovative Technology and Exploring Engineering (IJITEE), 8(3), 113-116.

Wahyuni, S. (2016). Curriculum Development In Indonesian Context The Historical Perspectives And The Implementation. Universum: Jurnal Keislaman dan Kebudayaan, 10(1), 73-82.

Winarno, W., Zuhri, M., Mansur, M., Sutomo, I., \& Widhyahrini, K. (2019). Development of Assessment For the Learning of the Humanistic Model to Improve Evaluation of Elementary School Mathematics. International Journal of Instruction, 12(4), 49-64.

Zainiati, H. S. (2017). Understanding the Cognition Process of the Students using the Internet as a Learning Resource. Jurnal Pendidikan Islam, 3(1), 57-68. https://doi.org/10.15575/jpi.v3i1.928 